\title{
A Comparative Study on the Effectiveness of Using Direct and Audiovisual Methods for Enhancing Students Listening Comprehension
}

\author{
Faidhatul Atiyah'), Lidiyatul Izzah 2) \\ 1) MTS Al-Hamid, Cilangkap Baru, Jakarta, Indonesia \\ 2)Universitas Muhammadiyah Jakarta, Tangerang, Banten, Indonesia \\ 1)faidhatulatiyah5@gmail.com, ${ }^{2)}$ izzahlidiyatul@gmail.com
}

\begin{abstract}
The present study aims to compare experimentally direct and audio-visual method in terms of their effectiveness in students listening comprehension. Another purpose of the study is to help the teachers to find out the most effective way of teaching listening in the classroom. This study was conducted in MTS Al-Hamid, and 46 students of two classes were selected as the sample participants. In choosing the sample, the writer used a cluster random sampling technique. The subjects were assigned as experimental and control groups. This research used post-test only toward the experimental and control group. Data were gathered through the listening test in both the control and experimental group. While the experimental group learned English by implementing the audiovisual method, the control group was instructed by the audiovisual method. In the end, the results were statistically analyzed. Based on the result, the use of audio-visual method had a positive effect on the enhancement of students listening comprehension.
\end{abstract}

Keywords: audiovisual method, listening skill, listening comprehension.

Citation APA Style: Atiyah, F., \& Izzah, L. (2019). A Comparative Study on the Effectiveness of Using Direct and Audiovisual Methods for Enhancing Students Listening Comprehension. English Language in Focus (ELIF), 2(1), 9-16.

\section{INTRODUCTION}

$\mathrm{L}$ istening is key to all effective communication. It is the process that enables the listener to comprehend, determine, and identify what the speaker is saying. In addition, listening can provide interest for enjoyment and social reasons (Vandergrift \& Goh, 2012, p. 5). Higher understanding of listening, therefore, will lead the learning language fun and easier and run effective communication. It is primarily the first step towards English language acquisition (Harmer, 2012; Hsueh-jui \& Liu, 2008). Having a good in listening ability implies having the capability to transfer information in oral communication. Without the capability in listening, the message will be misunderstood and the sender message can easily become frustrated or irritated.

Listening is considered as the most challenging skills in a second language. It normally consumes longer 
than other language skills and requires some learning process. As important as speaking skill, many people cannot communicate effectively unless both types of abilities are developed (Rost \& Wilson, 2013, p. 8). Listening is not just hearing, but feedback is required. It refers to the understanding of what the listener has heard, while the listener may repeat the sounds and text without real understanding (Hamouda, 2013). A listener listens to a speech in the form of the sound signals that are internally processed to create them in the meaningful utterance. This internal process involves a series of cognitive activities and conversational conventions, which cannot be immediately identified (Brown, 2010; Gilakjani, Sabouri, Pourhosein, \& Branch, 2016; Hamouda, 2013; Nadig, 2013; Rost \& Candlin, 2014).

In addition, numerous study was conducted to examine the issue in listening. Inappropriate metacognitive strategies become one of challenging factor in listening comprehension. A survey was created and validated by Vandergrift \& Tafaghodtari (2010) which examines the metacognitive awareness of second-language listeners, as well as, how they investigated the use of metacognitive strategies when listening to a spoken passage. The research disclosed five separate factors on predicting listening comprehension.

The first is problem-solving strategies that concern on how listeners infer the meanings of unknown words, use their experiences and general knowledge when interpreting the text (Rubin \& Roberts, 1987). The second is planning and assessment strategies that concern on how listeners prepare themselves for listening and evaluate their scores in listening (Hinkel, 2006). The third is mental translation avoidance strategies that concern on how listeners mentally overcome to translate a passage as they hear it to become skilled L2 listeners (Vandergrift, 2006). The fourth is self-knowledge strategies that involve knowledge about the complexity of the L2 listening task and the confidence and anxiety level during listening to the spoken passage (Chemers, Hu, \& Garcia, 2001). The last is attention directed strategies that listeners use to stay on task (Rost \& Candlin, 2014).

However, just being aware of these strategies is insignificant. Deci \& Ryan (1995) and Golchi (2012) investigated that a listener's motivation or insufficient emphasis on listening will influence whether he or she can use metacognitive strategies to help improve listening performance. As Vandergrift \& Goh (2012) states that the teacher should have wide ways in teaching listening comprehension to make sure that the students feel enjoy, happy and relax with the listening assignment. However, to assist learner improves their listening comprehension; linguists have implemented lots of teaching methods. The direct method and the audio-lingual method are two of the most popular listening teaching methods, particularly in second/ foreign language context. Each one of these methods has a distinct focus or priority.

Direct method. Over the past 100 years, the direct method has had a significant impact on English language teaching and many of the methods that followed certain aspects of its method, 
most notably the communicative method (Flowerdew \& Miller, 2005). In Germany and France around (1900), this method was established. It appeared as a response to the grammar-translation method. The concept of the direct method is that the English word, phrase or idiom be directly linked to its meaning. The concept of the direct link implies that the mother tongue of learner does not intervene. The students try to understand the foreign word or expression, as it is, without learning over the native language (Alhomaidan, 2018).

The principles of the direct method are summarized as follows. 1) Classroom instruction was exclusively performed in the target language. 2) Just daily vocabulary and sentences were taught. 3) Oral communications are carefully graded and organized around questions and answers between teachers and students in small, intensive classes. 4) Grammar has been instructed inductively. 5) New teaching points were introduced orally.6) Concrete vocabulary has been learned by demonstration, objects, and pictures; abstract vocabulary was taught through the association of ideas.7) Both speech and listening comprehension were taught. 8) Fixed pronunciation and grammar were stressed (Flowerdew \& Miller, 2005).

The advantages of the direct method can be listed as follows: 1) the method procedure enables students to be alert and participate. 2) Students can understand what they learn, think about, and then express their ideas. 3) This method can usefully be used from the lowest to the highest class. 4) It is a natural method that teaches language the same way as the mother tongue. Only the target language is used and the learning is contextualized (Alhomaidan, 2018).

Audiovisual method. This method was established in France as the result of the conclusions derived from the CREDIF -Centre de Recherche et d'Étude pour la Diffusion du Français- in the early sixties. This method is designed for teaching everyday language at the early stage of second/foreign language learning. It was based on a behaviorist approach, which found that language is developed through habitual growth. Based on the assumption that foreign language is a mechanical process and it is more effective if spoken form precedes written form. The stress was on oral proficiency and carefully- structured drill sequences (mimicry/memorization) and the idea that quality and permanence of learning are in direct proportion to the amount of practice carried out (Mourphy, 2018). In brief, audiovisual method is a method which refers to both sound and pictures which is typically in the form of slides or video and recorded speech or music; all are visual presentations that are shown by the teacher to the students.

The advantages of audiovisual method can be listed as follows: 1) the ability to ensure authentic language (what they are communicating effectively). 2) It can help learners to conceptualize ideas and get in-depth thought on the topic. 3) The motions that appeared in videos feature are always being motivational for the students. 4) it can provide the available information or substitute for books when they are not available on a particular topic. 5) the dramatic reactions can bring historical events and personalities in life. They allow the students' to observe and 
analyze human interactions (Ashaver \& Igyuve, 2013; Çakir, 2006; Dehaki, 2017; Yousofi, Davoodi, \& Razmeh, 2015).

\section{RESEARCH METHODOLOGY}

7 his research used the quantitative approach in the form of experimental design. Arikunto (2010, p. 310) states that experimental study has a purpose which means to explore whether there is an effect on something that is treated as the subject of the research. This research used quasiexperimental research that focused on non-equivalent control group design. In conducting the study, the writer took two classes. While one class is an experimental class taught by the audiovisual method and the other is control class instructed by the direct method. Both of classes got the same material, length of time, and the same teacher. The chosen topics for both methods were Fabel entitled: The Elephant and the Ant in video recorded format. These topics were selected because they met Field's (2004) suggestions of top-down and bottom-up processes and represented topics English language teacher candidates would likely encounter, such as linguistics, speaking, and reading. The result of those strategies was observed at the end to see the significant difference of students listening comprehension.

Additionally, the population of the study was the second semester of 2018/2019 academic years students of MTS AL-HAMID East Jakarta. There are 3 classes which consist of 23 students for each class. The population was about 69 students from all of the $8^{\text {th }}$ graders. Based on the limitation of the research, the sample of this research was the two classes of the $8^{\text {th }}$ graders of Junior High School. They were recruited and randomly assigned become two groups: direct method $(n=23)$ and audiovisual method $(n=23)$. This research began from $12^{\text {th }}$ of November $-12^{\text {th }}$ of May 2019.

In selecting the technique of the data collection, this research used posttest only toward the experimental and control group. There was no pre-test given to both groups in controlling for simple testing effect. In collecting the data, the writer used the test as an instrument of the study. The test is administered (after the treatment is given) to the participants of the groups in two sessions. The students were given 20 questions of Gap Filling Items for both classes, items in which the students have to fill a gap with the right words. Furthermore, the questions in the listening text typically represented question types used to assess language learner linguistic competence (Buck, 2001).

After getting the data from posttest, the writer analyzed by using statistic calculation of the t-test formula to determine whether there are significant differences between the two sample means or not. All submissions analyzes were performed on significance level 0 , 05.

\section{FINDING AND DISCUSSION}

o collect the data of this research,
the writer gave an instrument test
to the students to get the data about the difference between the students listening comprehension taught by direct method and audiovisual 
method. After the data was collected, the writer analyzed the data gained from the research. Based on the research finding, it showed that the scores of the experimental class in post-test were different. The lowest score of VIII-1 as a control class is 0 and the highest score of VIII-1 is 85 while the lowest score of VIII2 as the experimental class is 60 and the highest score of VIII-2 is 100 . The mean of students' scores in the post-test of VIII-1 as a control class is 55.00 and the post-test of VIII-2 as experimental is 82.17.

The following diagram presents the distribution frequency of students post-test in the control class:

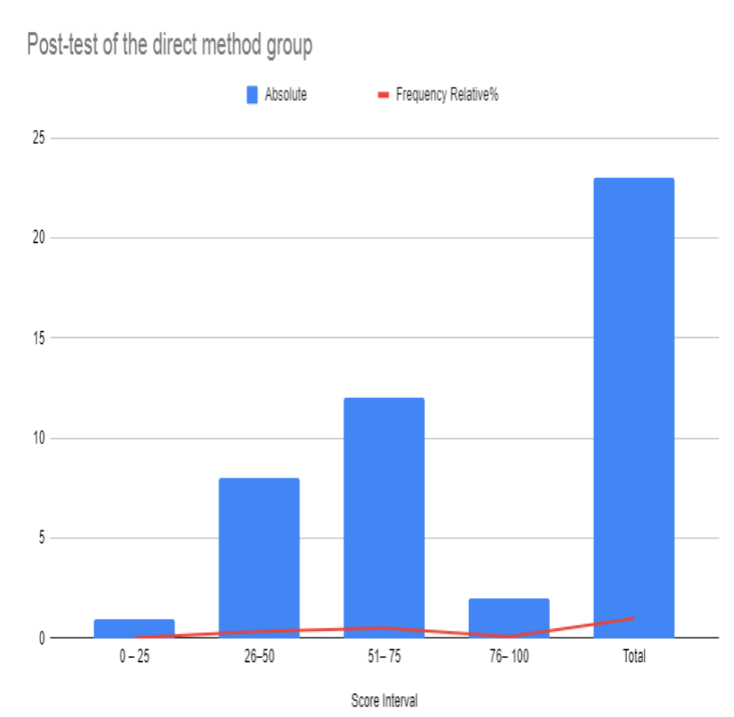

Figure 1. Control class students' posttest listening result

Based on the diagram frequency above, it shows that 1 student (4.35\%) got range scores $0-25,8$ students (34.78\%) got range scores 26-50, 12 students $(52.17 \%)$ got range scores 51 75,2 students $(8.70 \%)$ got range scores 76-100 for their listening comprehension test. The following diagram presents the distribution frequency of students posttest in experimental class:

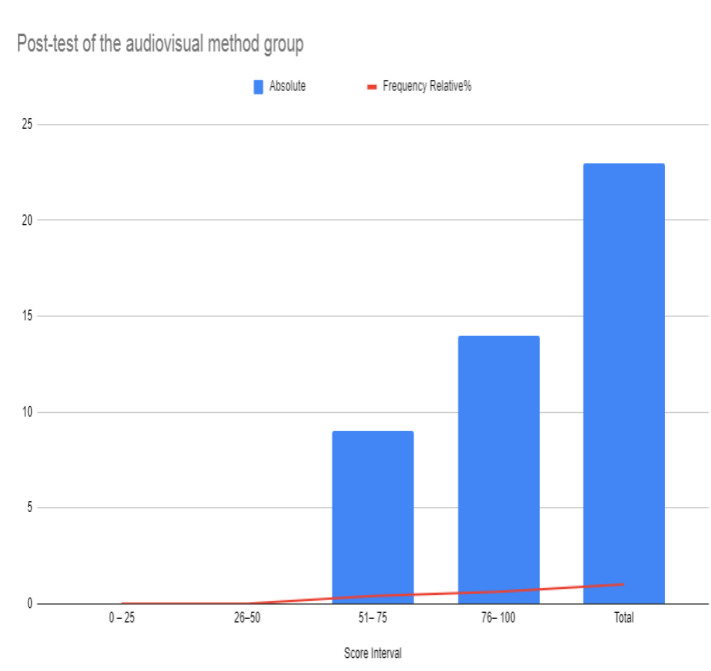

Figure 2. Experimental class students' post-test listening result

Based on the diagram frequency above, it shows that 0 student $(0 \%)$ got range scores $0-25,0$ student $(0 \%)$ got range scores 26-50, 9 students (39.13\%) got range scores 51-75, 14 students (60.87\%) got range scores $76-100$ for their listening comprehension test. As the research findings, it showed that the mean of students' post-test scores was 82.17. Then, to prove the hypothesis, the researcher calculated gained score by $t$ test. The t-test calculation showed that $t_{\text {calculation }}$ was 15.98 in the degree of freedom (df) of $44,(46-2=44)$. Then the degree of significance $5 \%$ of $t_{\text {table }}$ was 2.0154 .

In sum, a statistically meaningful difference was discovered $\left(t_{\text {calculation }}=15.98, d f=44, \quad p>0.05\right)$. The results of the data analysis showed that $t_{0}$ (t-observation) is higher than $t_{t}$ ( $t$-table). It indicates that the audiovisual method was more favorable.

\section{CONCLUSION}

his study examined differences in
the effectiveness of direct method
and audiovisual method in 
students listening comprehension. The research question asked, "Is there an experimentally significant difference between direct method and audio-visual method in terms of their effectiveness in students listening comprehension."

Based on the research conducted in second graders of students of MTS AlHamid, East Jakarta, it can be concluded that the audiovisual method performed significantly higher than the direct method. This result can be shown through the obtained scores of $t_{0}(t-$ observation) was 15.98. Meanwhile, $\mathrm{t}_{\mathrm{t}}(\mathrm{t}-$ table) is 2.0154 with significance $5 \%$ which means that audiovisual more effective or favorable. Therefore, these variables should be taken into consideration in future research comparing direct method and the audiovisual method in students listening comprehension. Further empirical research with a larger sample size is also suggested to examine the impact of both variables on comprehension of various text types.

\section{REFERENCES}

Alhomaidan, A. M. A. (2018). A Contrastive Study of the Direct Method and Audio-Lingual Method in Teaching English Speaking Skills. 6(2), 351-360.

Arikunto, S. (2010). Prosedur Penelitian Suatu Pendekatan Praktik. Jakarta: Rineka Cipta.

Ashaver, D., \& Igyuve, S. M. (2013). The Use of Audio-Visual Materials in the Teaching and Learning Processes in Colleges of Education in Benue State-Nigeria. IOSR Journal of Research \& Method in Education (IOSR-JRME), 1(6), 44-55. Retrieved from

www.iosrjournals.orgwww.iosrjour nals.org

Brown, H. D. (2010). Language Assessment: Principles and Classroom Practices. New York: Pearson Education.

Buck, G. (2001). Assessing Listening. New York: Cambridge University Press.

Çakir, İ. (2006). The Use of Video as an Audio-Visual Material in Foreign Language Teaching Classroom. The Turkish Online Journal of Educational Technology-TOJET, 5(4), 67-72. Retrieved from http://www.tojet.net/articles/v5i4/ 549.pdf

Chemers, M. M., Hu, L., \& Garcia, B. F. (2001). Academic Self-efficacy and First Year College Student Performance and Adjustment. Journal of Educational Psychology, 93(1), $\quad$ 55-64. https://doi.org/10.1037/00220663.93.1.55

Deci, E. L., \& Ryan, R. M. (1995). Human Autonomy: The Basis for True SelfEsteem. In M. H. Kernis (Ed.), Plenum Series in Social/Clinical Psychology. Efficacy, Agency, and Self-esteem (pp. 31-49). Retrieved from https://psycnet.apa.org/record/199 5-97476-002

Dehaki, M. M. (2017). The Effect of Watching Videos on Listening Comprehension of Iranian Intermediate EFL Learners in Public Schools Mohsen. Journal of Applied Linguistics and Language Research, 4(6), 214-222. Retrieved from http://www.jallr.com/index.php/JA LLR/article/download/678/pdf678

Field, J. (2004). An Insight into Listeners' Problems: Too Much Bottom-up or Too Much Top-down? System, 32(3), 363-377. 
https://doi.org/10.1016/j.system.2 004.05.002

Flowerdew, J., \& Miller, L. (2005). Second Language Listening: Theory and Practice. New York: Cambridge University Press.

Gilakjani, A. P., Sabouri, N. B., Pourhosein, A., \& Branch, L. (2016). Learners' Listening Comprehension Difficulties in English Language Learning: A Literature Review. English Language Teaching, 9(6), 123-133. https://doi.org/10.5539/elt.v9n6p1 23

Golchi, M. M. (2012). Listening Anxiety and Its Relationship with Listening Strategy Use and Listening Comprehension among Iranian IELTS Learners. International Journal of English Linguistics, 2(4), 115-128.

https://doi.org/doi:10.5539/ijel.v2n 4p115

Hamouda, A. (2013). An Investigation of Listening Comprehension Problems Encountered by Saudi Students in the EL Listening Classroom. International Journal of Academic Research in Progressive Education and Development, 2(2), 113-155. Retrieved from http://hrmars.com/admin/pics/188 2.pdf

Harmer, J. (2012). Essential Teacher Knowledge. Harlow: Pearson Longman.

Hinkel, E. (2006). Current Perspectives on Teaching the Four Skills. TESOL Quarterly, $\quad 40(1), \quad 109$. https://doi.org/10.2307/40264513

Hsueh-jui, \& Liu. (2008). A Study of the Interrelationship between Listening Strategy Use, Listening Proficiency Levels, and Learning Style. ARECLS, 5, 84-104. Retrieved from https://research.ncl.ac.uk/media/sit es/researchwebsites/arecls/liu_vol5 .pdf

Mourphy, S. (2018). What is the audio visual method? - Quora. Retrieved from

https://www.quora.com/What-isthe-audio-visual-method

Nadig, A. (2013). Listening Comprehension. In F. R. Volkmar (Ed.), Encyclopedia of Autism Spectrum Disorders (p. 1743). Springer.

Rost, M., \& Candlin, C. N. (2014). Listening in Language Learning. New York: Taylor and Francis.

Rost, M., \& Wilson, J. (2013). Active listening. New York: Routledge.

Rubin, R. B., \& Roberts, C. V. (1987). A Comparative Examination and Analysis of Three Listening Tests. Communication Education, 36(2), 142-153. https://doi.org/10.1080/03634528 709378655

Vandergrift, L. (2006). Second Language Listening: Listening Ability or Language Proficiency? The Modern Language Journal, 90(1), 6-18. https://doi.org/10.1111/j.15404781.2006.00381.x

Vandergrift, L., \& Goh, C. C. M. (2012). Teaching and Learning Second Language Listening: Metacognition in Action. New York: Routledge.

Vandergrift, L., \& Tafaghodtari, M. H. (2010). Teaching L2 Learners How to Listen Does Make a Difference: An Empirical Study. Language Learning, 60(2), 470-497. https://doi.org/10.1111/j.14679922.2009.00559.x

Yousofi, N., Davoodi, A., \& Razmeh, S. (2015). A Comparative Study of Audio and Video Listening Practices 
Eng̉ish Language in Focus (ELIF), 2 (1), 9-16. https://jurnal.umj.ac.id/index.php/ELIF

in a Private Language Institute in

www.ijeionline.com

Iran. International Journal of

Educational Investigations, 2(3), 16-

26. Retrieved from 